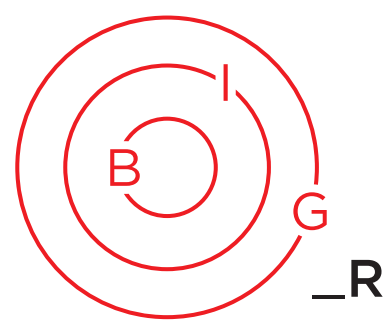

ESSAY

SPECIAL ISSUE

\title{
Seme Border, Nigeria: Safety and Collective Vulnerability
}

\author{
Willie A. Eselebor *
}

The induced border closure at Seme Border, Nigeria, on March 23, 2020 is just one among other closures carried out from 1984-2020. The closure brings to the fore issues of safety and collective vulnerability of the border communities and the existing coping mechanisms for addressing their fears. In the absence of constructive engagement with the vulnerable, the people often resorted to self-help by creating alternate routes (bush paths and waterways) thereby rendering the securitisation of border security (Border Drill) management ineffectual. In decision-making and for a successful implementation, it is important to allow for a buy-in from those affected by such policy.

\section{Introduction}

The Seme Border closure of 2020 has fundamentally changed lives. It caused dislocations in border governance and bordering activities because it has compelled self-isolation and social distancing for safety. Nations responded by shutting their borders to prevent spread, an action that pointedly demonstrated the role of borders in public health and safety of vulnerable groups.

According to media reports, the first person (whose name was not disclosed) that arrived in Lagos, Nigeria

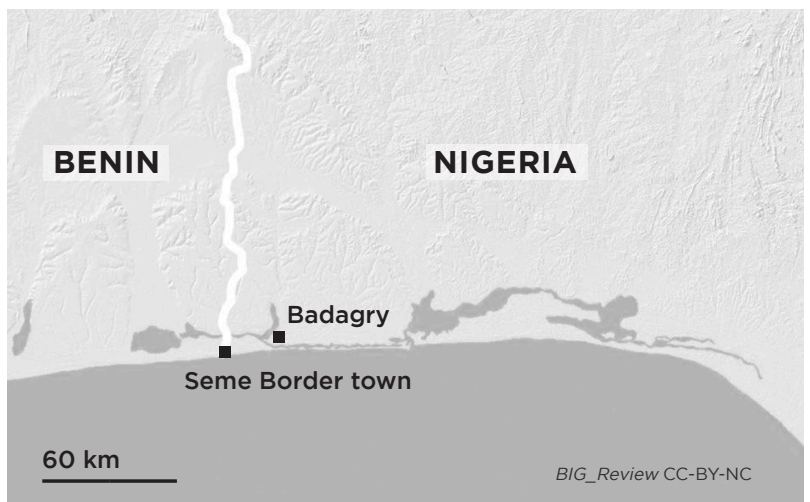

on February 20, 2020 was an Italian. Following his arrival and subsequent visit to Lafarge Africa Plc. a leading sub-Saharan African cement company, the land border of Nigeria with Benin was closed on March 23, 2020. Militarised personnel were immediately deployed to enforce the restriction on movement. In view of this development, border users diverted to bush paths as alternative routes to evade security clearance. Seme Border town, the busiest gateway to markets in Africa, is the geographic focus of this study. ${ }^{1}$ This research looks at the situation before the outbreak; the existing governance regime; and how the closure has shaped the way we think and do things.

Scholarly discourse on borders often interrogates the interplay of sovereignty and the deployment of security to legitimize governance of the territorial space. In context, the governance of mobility is of interest, based on gaps left unexplored in literature. This throws up the issue of security threat as a justification for border closures because the control of borders remains an exclusive preserve of the state. Closure affects the livelihood and the daily encounters of bordering. Conversely, the policy, practice, perception

* Willie A. Eselebor, PhD, Institute for Peace \& Strategic Studies, University of Ibadan, Nigeria.

Email:willivizz@gmail.com Webpage: http://ipss.ui.edu.ng/waeselebor Facebook: Willie Eselebor 
approach, remains helpful in countering the notion of territorial borders, in which Kolossov believes that "The boundary is not simply a legal institution designed to ensure the integrity of state territory, but a product of social practice" $(2005,625)$.

Kolossov's viewpoint converges with the present thinking that the custody of the border management initiative is not the sole responsibility of the state rather, it involves other interested stakeholders-border communities. Unfortunately, the communities were excluded from the decision to close the border. The current border closure or Border Drill is an example of intervention, managed by a pool of federal agencies to the exclusion of the federating state, local government and the border communities. Exclusion usually generates tensions and uncooperative attitudes from border inhabitants. This study has been organised into four sections. Section one introduces the discourse; section two examines the status of Seme Border before and during closure and section three, presents the findings of post-closure Seme Border. Section four consists of the summary, observed changes and conclusion.

\section{Seme Border Before and During Closure}

Seme is on the coastline, along the Lagos-Abidjan corridor, with a shared 773-kilometre border with Benin Republic in West Africa. It is one of the busiest land routes in West Africa and is used for commuting and commerce. It has a full complement of border security agencies, including Immigration, Customs and Port Health Services, among others. Administratively, it is under Badagry-West Local Council Development Area (LCDA) of Lagos State, Nigeria. The border is located on a new multilateral one-stop-border facility that opened on October 23, 2018. Nigerian operational activities of Immigration and Customs clearance are carried out inside Beninese territory.

Historically, Nigeria and Benin are culturally linked but both countries experienced different colonial history (Nigeria-Britain and Benin-France). Since 1889, part of the Benin monarchy has owed allegiance to the old Oyo Empire in Nigeria. Both communities in the border region speak Ogu or Egun and Yoruba languages in the South-Western parts of Nigeria

Benin and Nigeria are both member nations of the ECOWAS but the economic relationship is asymmetric, with Nigeria asserting more pressure on the Francophone country. Due to these power dynamics, Benin operates an entrepôt port, where goods are imported, stored in warehouses, and re-exported to Nigeria through porous borders. A high level of smuggling of prohibited goods, trafficking of humans, arms, and hard drug take place unabated. Trading activities are mostly informal and undocumented and often lead to security threats and revenue losses to Nigeria. This unregulated activity has led to about four Seme Border closures in April 30, 1984; October 08, 2003; August 19, 2019 and March 23, 2020. The last two closures which this article examines are classified as Border Drill, a new approach in border policing. The last two closures still subsist and the reason adduced for the March 23, 2020, closure remains public health safety.

Border Drill refers to a combination of task-force put together by the Office of the National Security Adviser (ONSA) to enforce the Presidential Directive on border closure of August 19, 2019. The team comprises core security agencies such as the military, police (border patrol), customs, immigration, and the department of state security. Border Drill is the deployment of Special Forces with a mandate to enforce border closure and restrict mobility of persons and goods entering and exiting Nigeria's land borders. However, certain categories of returnees of Nigerian descent were granted entry in strict compliance with the Nigeria Centre for Disease Control (NCDC) protocols on testing and isolation. The following arrivals were documented from field survey:

\begin{tabular}{|c|c|c|c|}
\hline $\begin{array}{c}\text { Arrival } \\
\text { date }\end{array}$ & $\begin{array}{c}\text { Number of } \\
\text { persons }\end{array}$ & $\begin{array}{c}\text { Point of } \\
\text { departure }\end{array}$ & Isolated in \\
\hline $\begin{array}{c}\text { April 05, } \\
2020\end{array}$ & 67 & Cotonou, Benin & $\begin{array}{c}\text { Badagry, } \\
\text { Lagos }\end{array}$ \\
\hline $\begin{array}{c}\text { May 16, } \\
2020\end{array}$ & 53 & Accra, Ghana & $\begin{array}{c}\text { Badagry, } \\
\text { Lagos }\end{array}$ \\
\hline $\begin{array}{c}\text { June 10, } \\
2020\end{array}$ & 13 & $\begin{array}{c}\text { Paris via } \\
\text { Cotonou, Benin }\end{array}$ & $\begin{array}{c}\text { Badagry, } \\
\text { Lagos }\end{array}$ \\
\hline
\end{tabular}

Table 1: Seme Border returnees during closure. During the period of fieldwork, three dates (above) were designated for Nigerians to return under special conditions in which the Nigeria Centre for Disease Control activated protocols for screening, testing, and isolation. Source: field surveys.

As of July 15, 2020, 167 persons had been screened, admitted and isolated in centres in Badagry. ${ }^{2}$ There were no records of departure.

The 'partial' closure of Seme Border from August 19, $2019^{3}$ and the continued closure from March 23, 2020 till date, implies that there have been two subsisting orders in force. This has impacted negatively on the border community and equally led to diversion to bush paths and waterways for commercial activities. Some of the border community stakeholders interviewed revealed that most returnees prefer to use the porous bush paths so as to evade the mandatory isolation for 14 days. It was observed that the use of facemasks was not so common with motorcyclists, traders and crossers, who periodically ferry passengers across the bush paths and maritime routes. 
Borders in Globalization Review | Volume 2 | Issue 1 | Fall/Winter 2020

Eselebor, "Seme Border, Nigeria: Safety and Collective Vulnerability"

\section{Post-closure Status of Seme Border}

The border communities experience regulated controls and this has led to paralysis in informal trading activities. Due to restriction on movement, preparedness in terms of healthcare facilities, sanitation and testing facilities could not be assessed. The nearest health facility is located in Badagry, about 15 kilometres away but expectations that government should set up a testing centre at the border crossing did not materialise, thereby calling attention to issues of safety and vulnerability of border community people. From interviews carried out with frontline workers, NCDC border procedures on health security and environmental hygiene such as steam cleaning, disinfection and surface decontamination of border facilities, hand washing, waterless sanitisers were not strictly enforced. Personnel protective equipment for border security agencies were in short supply and therefore constrained enforcement to reducing infection.

Seme Border is exemplified in a case study of two border closures (August 19, 2019 \& March 23, 2020) which affected and exerted tensions on the border communities. Economic activities had reduced considerably due to the earlier closure of 2019 and later worsened with the outbreak in 2020. Paradoxically, these two factors boosted patronage of unauthorised channels. Field visit to Iyafin waterways which connects Nigeria with Benin attest to the shift to locally constructed boats (wooden

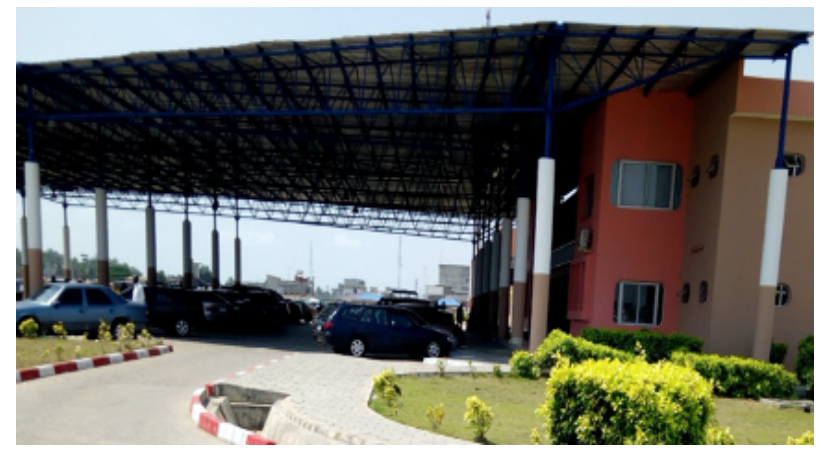

Figure 1. Seme Border during Border Drill closure. Photo credit: W. Eselebor, August 2019.

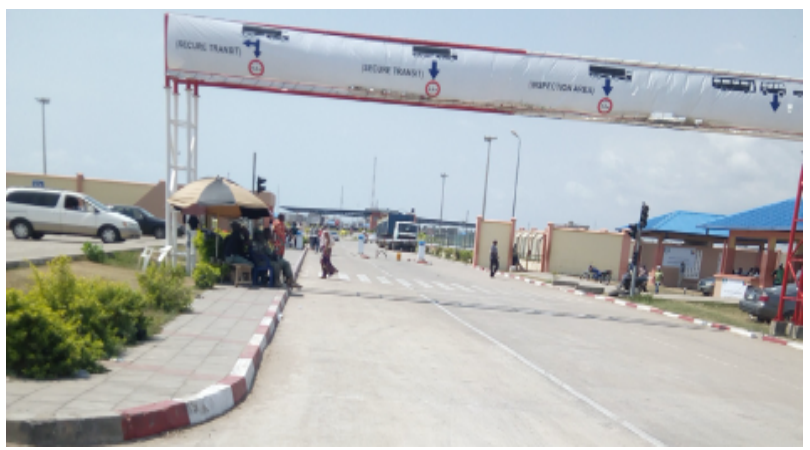

Figure 2. Seme Border during COVID-19 closure. Photo credit: W. Eselebor, April 2020. canoes) as means of transportation. The newly created routes undermine the essence of closure. The capacity to conduct cross-border testing or laboratories to analyse samples are unavailable in the maritime routes.

What has changed (or will) in the context of Seme Border as a post transit hub are unwillingness by international travellers to voluntarily submit to health screening. People are becoming more attuned to commuting through unauthorised routes and usage of waterways. Invariably, when the border is opened for normal clearance activities, it is doubtful if passengers will adhere to social distancing because awareness of the risk factors is lacking in the rural communities. This is because the non-provision of relief packages to cushion the adverse effects of 'stay-at-home' restrictions also challenged the survival strategies of the border communities.

In addition, Customs and Immigration clearance procedures will transit from manual to technological. As suggested by a respondent, it is envisaged that if the border is opened, the health security threat of the pandemic will make searches of goods or people without protective equipment a risky exercise. This also extends to physical handling of passports and placing of index fingers on scanners. These are new challenges that will require deployment of technology that will fundamentally alter the way agencies will work in the future. However, the fact that the border is still on lockdown makes it difficult to postulate.

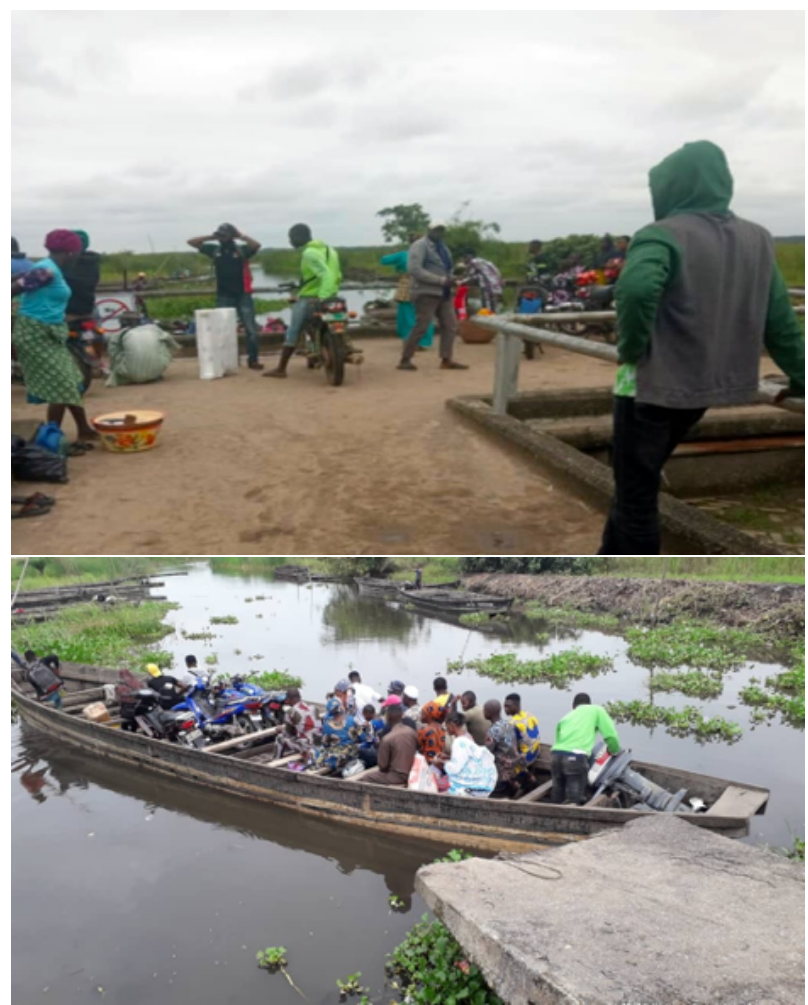

Figure 3. Marine border at Iyafin-Badagry, Lagos. Photos credit: W. Eselebor, April 2020. 
What will remain unchanged are smuggling or criminal activities. Smuggling as an activity may have substantially increased due to the border closure, whereas the Border Drill was meant to reduce it to zero. Evidences in the local markets around the border and Badagry town, about 15 kilometres away, suggest an overflow of prohibited goods like parboiled rice, poultry products and other consumables. This calls to question the effectiveness of the border closure regime in place. Consequently, it has led to a spiral increase in the prices of staple food items. It has been observed that there is increased smuggling of petroleum products through maritime routes not covered by Border Drill. So, smuggling into Nigeria and outwards to Benin has remained unchanged.

\section{Summary and Conclusion}

In summary, this study has attempted to situate contemporary problems generated by outbreak and its impact on borders to determine what has changed or remain unchanged while focusing on safety and collective vulnerability in Seme Border, Nigeria. A detailed explanation of the border was undertaken to highlight its importance as one of the busiest commercial gateways in the West African sub-region. However, given the nature of transnational security threats, the border has been closed four times from 1984-2020 and this has led to diversion and resort to the usage of bush paths and maritime routes for commuting. The securitisation of border controls through the adoption of Border Drill has created alternative routes, thus undermining border security. The creation of slippages constitutes health security concerns, as findings revealed that majority of persons travelling through waterways as an outcome of restrictions, do not comply with NCDC guidelines as part of the changing dynamics of health security content of border management.
In conclusion, there seems to be no terminal date for the end of induced border closure; and so, we must begin to accept the new culture of transition by wearing facemasks, washing and sanitising hands, avoiding overcrowding and managing transmission of cross-border health security threats. Border Drill does not appear to be effective because there has been a relative increase in smuggling and criminal activities, due to porosity of borders and largely because the capacity to cope by the local communities have waned. The use of robots and biometrics in passenger clearance will reduce physical contact.

\section{Notes}

1 Seme Border remained closed since August 20, 2019. In terms of methodology, to source data was difficult. Individuals who volunteered information were security agencies and selected border community people.

2 About three hotels were reserved for international travelers located in Badagry (names not mentioned as part of ethical considerations). Travelers are to self-isolate and undergo NCDC testing before discharge. No positive case was recorded out of the 167 persons screened.

3 Commuting was restricted from 6 am to $6 \mathrm{pm}$, which makes it partial closure. Hitherto, the border was opened for twenty-four hours a day. Seme Border therefore had two subsisting border closures; one related to security threats and the other necessitated by the outbreak of the pandemic.

\section{Works Cited}

African Union. 2017. Draft African Union Border Governance Strategy. Available: http://www.peaceau. org/uploads/2018-06-14-aubgs-e.pdf

Kolossov, V. 2005. "Border Studies: Changing Perspectives and Theoretical Approaches" Geopolitics, 10(4), 606-632. https://doi.org/10.1080/14650040500318415 